\section{A GLIMPSE INTO THE SPIRITUAL STRUCTURE OF THAI FOLKLORE ${ }^{1}$}

\section{Kovit Anakechai "Khemananda""}

\section{Forward}

For those who want to examine the spiritual depth of Thai people, they may be confused by the flexibility of the Thai character and the change of values in present Thai society. The flexibility of the people on the Indo-China peninsula seems to be misperceived by westerners, and the changing of values, becoming more westernized, have alienated the local people from their own spiritual roots. Even those highly educated people who are aware of this alienation and who try to evaluate and preserve their roots are possibly alienated from the spiritual structure of their own culture. The political conflicts and the growth of nationalism are somehow problems to gaining a purely objective and spiritual understanding. In order to free our observations from all prejudices we must be aware of our own gratification at being more westernized.

If art and culture is defined by time (its period) which makes it possible for evaluation through scientific analysis, we will acquire a great deal of understanding of art and culture psychologically, politially,economically, etc. Our approach through such definition is

1 This paper is based on the the paper presented at the International Conference on Thai Studies August 22-24, 1984, Bangkok. 2 Buddhist scholar, Poet, Writer and Painter destined to lead to the understanding of a visible form and pattern of art and culture which is created for social demand. Therefore, art and culture geo-socialises their form according to time (its period). But for spiritual demand, the invisible structure of the timeless nature of art and culture really needs another approach. And the destiny of such spiritualization is not merely to have but to be -- to realise Suchness. Otherwise our standard of evaluation will become alienated from art and culture. We may have the majestic form of art and culture for exhibition and fashion but possibly we can never live with it as the way. This alienation is, notably, the cause of the decline of art and culture. The lack of spiritual wakefulness will formulate the grand and fantastic expression for gratification of sensualism or politics more than for peace and pure wisdom, for authority rather than humanity.

This is the fact of our age of so-called modern living, that is, we may possess advanced technologies to gratify our sensual demands, but in fact we acquire much less spiritual happiness than people did in the olden days. Our mechanical thinking leads us to psychological and philosophical interpretation. That is, our approach to art and culture is about the visible forms and behaviour and our conclusions come therefrom.

The epics of the world are among those things of art and culture which need proper evaluation, not merely as a matter of the intellect or entertainment but, notably, as a whole stucture of spiritual growth. It is not just about the hero and heroine, but about any individual whose obstacles and victories are sym- 
bolized by demons and deities. It is the journey into inner life of the mystical individual in association to the outer world. The realization of our inner being is symbolized by the enthronement of a heroic prince after killing the demons, having received the bliss of Dharmic god and having brought back peace to the whole region. Specifically, such a spritual structure of folklore or epic are mostly the same because it is simply the only great journey of mankind to the Supreme-Being, be it god or Bhutathara or Lord Amitabha of the Buddha-Realm. Religiously speaking, the whole history of mankind is this ultimate journey.

When we examine those epics or other forms of art psychologically, it is possible to be misled by those psychological theorems since we are using it as a logical basis to explain the spiritual function of symbolism or personification. Those characters in the epics are not people but spiritual symbols of the formless within. And the journey of the heroes or the great war or the setting is not physical form since the only way to visualize the invisible is to use symbolism or personification. That is the combination of the invisible and the visible of spiritual expression in art.

The complexity is here: personification is analogy. Let us take an example from the Ramayana. Rama is a historical person, a human who has attained sublime bliss from god. His actions are for the Love (Bhakti) of god and for the welfare of the world. Indian people have praised him as an ideal king, lover and prophet. His sayings have become Dharma teachings. Therefore, he is a god to Indian people. In the Ramayana, Rama is an ideal man as a character in the epic and a historical figure, but spiritually he is Truth (Satya). Hanuman -the lord of the monkeys is Bhakti (love of god), while Sita, Rama's wife -- an ideal woman as a character, is spiritually Atman. Ravana is Egoism (Ahamkara), who resides in the mysterious Island of Sri Lanka, which no man can approach, except Hanuman -- the great faith in god. However, in praise of god, Rama as a man of god accompanied by his soldiers must build the Setubandha (Bridge of Testament) by the power of god in order to kill Ravana and to re-unite with his beloved wife and to establish the total peace to the whole region, which applies literally to the whole world. That is the spiritual bridge which links Ramesvaram of south India with Talaimana of north Ceylon (Sri Lanka).

Place, time, distance, beasts, monkeys, bear (Chambhuvana), divine weapons, cities, demons, rivers, jungles, mountains, rainfall, wind, battles and adventures etc, that is all elements of the Ramayana are not merely drama; their spiritual meanings should be understood and appreciated.

\section{The Common Ground and Spiritual Structure of Indian Epics}

In the 14-year journey of Rama, Sita and Lakshman, they killed a number of demons and received divine bliss. The names of the demons have spiritual meanings. For example, the first demon, Parasurama (Ramasura in Thai) who was killed by Rama, which is the com- 
bination of Parasu and Rama suggests Rama the beast. It means the animal instinct in man which, if we can subdue it, will enable us to receive divine power. Herein, Rama, after killing Parasurama, received the divine arrow of Brahman, which he could call for from god wherever and whenever he should need it. Another example is Marica, (Marish in Thai) it has the same root as the Latin word for Mirage. (the name of the younger brother of the great Demon, Ravana;) Ravana sent him in disguise as a golden deer to attract Sita and deceive Rama and Lakshman. Illusion arose then, and Truth (Rama) and Atman (Sita) were separated.

The most interesting symbol is when Rama, lamentating for thr loss of Sita, sent his generals everywhere in hope to find his beloved wife. Only Hanuman, the great Bhakta, can go down to Patala -- the deepest Realm of our being. Hanuman saw the endless tunnel, and he entered the shining underworld city called "Svayam Prabhu" which means 'The Realm of Spontaneity' where he received news of Sita's whereabout.

By meditation and faith or Bhakti in god, one will reach the realm of Spontaneity, and attain wisdom to realise Atman, understanding life as a whole, both the external and the inner. Here on the Hinduistic basis, of which the ultimate aim of life is to attain Eternity, the Atman or the pure self is liberated and united with the Supreme Being -Paramatman.

By absorbing into oneself, one enters the state of pure being by power of trance but cannot maintain it permanently. Only Hanuman, with the power of the god could fly to meet Sita on Lanka Island, but he had no rights to take Sita back to Rama unless the gods created the divine bridge (Setubandha) for Rama and Ravana was defeated. Here, in The Monkey God (Sei-Eew-Ki, Journey to the West, the Chinese Epic of the Ming Dynasty), the Monkey God could fly to the "Thus-come" (Chinese - Yulai), but he could not stay unless he was accompanied by his group. ${ }^{2}$

All demons, therefore, were obstacles for Rama, but after Rama subdued them, they manifested themselves as the divine signs to guide Rama to reunion with Sita. As for Ravana, the Master of demons and the King of the ideal city Lanka, the author made Rama kneel down to the dying Demon Ravana in order to learn policy and administration from him. Ravana whispered to Rama that from the beginning, he had adored Rama. We have a glimpse as to how one who attains bliss from God can learn to use demoniac arts for the benefit of the country.

The summary of Ramayana is herein: as a human being but with the power of god, after more than 14 years of devotion by great austerities and sacrifices, one can re-unite with oneself (Atman) and attain the bliss from God.

\footnotetext{
${ }^{2}$ The Monkey God is the Chinese Epic by Wu Chen En which had imitated the spiritual structure of Ramayana.
} 
In Mahabharata, the Pandava brothers had to roam in the wilderness for 12 years. Finally, by the help of Lord Krishna, Arjuna, the hero prince, showed sublime faith in Atman by 'killing' his own relatives and teachers. It sounds terrible for dharmic people who cling to the precept of 'no killing' and merely understand Mahabharata as religious poetry. But since such action, 'killing', is 'to kill all defilements which one loves as if they were close relatives and gurus, the killing in Bhagavadgita was the great action guided by God (Lord Krishna) not the historical battle at Kuruksetra field (near Indapath or present Delhi). It was the great battle within the human heart. Thereby, the Bhagavadgita is the most sacred text dear to the hearts of the Hindus and is appreciated by the whole world. The author, Vyasa, had taken the outer war to symbolise the inner war, external rider of the chariot for god within. The profound teaching of Lord Krishna for Arjuna is the heart of this great Epic as its whole structure is the spiritual journey undertaken to unite with god.

After victory, Arjuna, with his brothers and wife, led an austere way of life. Later, Yudhishthira alone roamed into the timeless jungle, the great darkness without stars, called Kanaka, and finally entered heaven. Standing in front of the supreme god, He saw Durayodhana, his antagonist standing near god, next to himself. For one who knows god sees everything as the manifestation of god and in god from the beginning. And to attain the sublime knowledge of the perfect man, Yudhishthira was to see his enemy Durayodhana perfected in god as well.
This is not historical or archaeological fact but a glimpse of spiritual structure. The depth of Indian epics is linked to Thai folklore. It is undeniable that India is the mother of the culture of Thailand and other countries in the peninsula of Indo-China.

\section{The Socializing Effect of Thai Original Folklore and its Mis- understanding}

Ramayana, Ramakirti and the Journey to the West

The Thai Ramakirti came from Ramayana which has been adopted andadapted. Thai kings, who, being Buddhists, traditionally led and ruled the country by Dharma, both of Brahmanism and Buddhism, created the Thai Ramakirti, which is more Buddhistic. But this adaptation in the form of poetry has bereft its spiritual essence. Wu Cheng En (1500-1582 A. D. Ming dynasty), the author of The Journey to the West, was more successful in keeping Buddhistic spirituality as well as poetic values. The three beasts: Ngo-Kong, the monkey, Poi-Kai, the pig, and Sua-Jeng, the water demons respectively represent prajna (Ngo-kong is Chinese for wisdom and emptiness), Sila (Poi-kai, is Chinese for eight precepts) and Samadhi (Sua-jeng is Chinese for the mountain of sand which is underdeveloped). The monkey is not Bhakta (faith) as Hanuman in Ramayana but wisdom, and instead of defeating Ravana in Lanka, the destination of the journey to the west is to receive the Tripitaka from the Buddha in India. We may be confused about the sense of time in the epic; Hieun-Tsang was a historical person some 1000 years after the Buddha's 
time, but since the Buddha here is Buddha Nature in man, in all of us, and Hieun-Tsang is the devout mind accompanied by wisdom, precepts and meditation, the end of the journey means the mind has realised Buddha Nature that resides within. This is how Hieun-Tsang and his disciples could approach the Buddha.

In the Thai Ramakirti, Hanuman symbolises both wisdom and faith. The addition of some characteristics and actions of Hanuman makes the Buddhistic expression perfect. For example, the episode of the burning of Lanka: in Ramayana, Hanuman extinguished the fire burning his tail at Ganga River which flowed from Heaven. In the Thai Ramakirti, Hanuman put his burning tail in his mouth, following the suggestion of a rishi who gave him a riddle: "Water in a small well can extinguish a great fire" This might be interpreted that one can perform a great act but somehow cannot free oneself from petty problems.

To get rid of the big ego is a real difficulty for mankind. Rama's arrows shot down a number of the heads of Ravana, but they always multiplied. In the Indian Ramayana, the fall of Ravana (ego) was brought about by the divine arrow, but in the Thai Ramakirti, Ravana had no heart within himself for he left it with his master rishi, so he was seemingly immortal. Hanuman went to the rishi's ashram to take the box containing Ravana's heart which enabled Rama to bring the king of demons down with his Divine arrow. To destroy the Ego, according to Buddhism, is to see into Sunnata (emptiness) of things -- the five Skhandhas are empty.

\section{Thai Folklore}

Thai folklore, which contains spiritual meaning, whether they were Buddhist tales or were created locally in Siam is more or less influenced by Ramayana, and its spiritual structure educated the people generation after generation in the glorious past. But this aspect of the Thai folklore disappeared in the Ratanakosin period which turned pure art into majestic decoration, diminishing its spiritual depth and vitality. Pannasjataka (The 50 Birth Stories of the Buddha) which contains several stories of spiritual concerns needs concentration to understand, for its structure originally was not just concerned with dramatic poetry which is an inadequate adaptation, concentrating on intellectual not spiritual aspects of the stories. The greatest loss is particularly the changing and the distortion of the names or terms that carry symbolic meaning, which are the keys to understanding the spiritual implication of the content.The natural growth of the origin mind or Bodhi citta (often symbolised in the form of the miraculous child, born to be a hero with divine weapons in hand) suggested by the works, thus, is left out.

Those folklore well-known among the Siamese in the olden days (or even today among older Thais), are Suvarnasangkha Jataka (Sangthong), Rathasena Jataka (Pra Roth-Meree), Sudhan Jataka (Pra Sudhon -- Nang Manohara), and Samudraghosa Jataka, Bahalagavi Jataka (Gavi).

In this paper, three epics are discussed to illuminate the depth of Thai spirituality with regards to Buddhism. They are: 
1. Sudhan Jataka or Pra Sudhon--Nang Manohara

2. Suvarnasanakha Jataka or Sangthong

3. Rathasena Jataka or Pra Roth-Meree

\section{The Sudhan Jataka or Pra Sudhon-Manohara}

The youngest daughter of Dumaraja, the Vijadhara king (one who possesses knowledge) who resided at Kailasa Mountain, named Manohara accompanied by her six Kinnari (half-human / half-bird) sisters to bathe in a pond amidst the jungle. A hunter stole her wings, disabling her from flying away with her sisters. After capturing her, the hunter offered her to the crown prince, Sudhan, as his wife. They fell deeply in love with each other. Later the king, Sudhan's father, sent him to battle with a neighbouring country. On his return he found that his beloved wife had fled because a jealous minister had attempted to burn her as a sacrifice to god, in order to get rid of her. Manohara was able to regain her wings and tail and flew back to Kailasa Mountain. She left three treasures behind -- a shawl, a diamond ring and magic medical powder -- with a hermit, instructing him to hand them over to Sudhan in order that he might follow her. She also gave an instruction about the difficult and privilous journey in which Sudhan would have to sacrifice his being. But with the guidance of a small monkey (sati or mindfullness) who was to guide him to the ends of the human realm and by the right use of the three treasures, he would successfully overcome all obstacles on the way.
A pictograph was provided in order to guide Sudhan along the pathless journey to Kailasa Mountain for the reunion. The great journey to be reunited with his beloved wife took seven years, seven months and seven days. (The length of time necessary in practice satipatthana -- a kind of meditation -- to finalise the goal -- liberation). Facing several obstacles which were foretold by Manohara, he overcame them all with the use of the three treasures (symbols of Sila, Samadhi, Panna). Having reached the dark jungle and countering the great demon (Avijja or ignorance), Sudhan shot him down and walked over the demon's head. He crossed the river of acid by the python bridge and hid among the feathers of the great bird king. He came across a jungle of thorny cane where he felt himself in great aloneness and passivity. Suddenly, Sudhan heard news of Manohara from a conversation among enormous birds nestling on the giant banyan tree. By hiding in the feathers of the bird he reached Suvarnagar (Golden City) of Kailasa Mountain. There he put the diamond ring into the pot of sacred water for Manohara's bath. With great joy she realized the coming of her beloved Sudhan.

After the King of Knowledge had tested Sudhan's power in various ways, Sudhan was set to the last test to determine whether his recognition of Manohara was perfect. By the help of Indra, who was in the form of a golden fly moving around Manohara's head, Sudhan recognised his beloved wife, using his magic power to discern her from her sisters, all of whom looked alike. 
Sudhan and Manohara accompanied the king of Great Knowledge back to the city of Sudhan's father. The enthronement ceremony for Sudhan as the new king was held. After the great celebration, peace reigned over the whole region thereafter.

\section{Summary of Spiritual Glimpse}

Sudhan is the Bodhi mind; Manohara is spiritual happiness or pure joy or bliss of peace. The Bodhi mind realizes the absence of bliss of peace. The three treasures -- the shawl, the powdered medicine and the diamond ring -- are Sila (a shawl covers and protects the body), Samadhi (the powdered medicine which Sudhan used constantly along the way to Kailasa means continuous application of samadhi in every activity, particularly in solving problems), Panna (the diamond ring is known among Buddhists, both Mahayanists and Theravadians, as the symbol of wisdom).

The small monkey who guided Sudhan along the path of the human realm is sati (mindfulness) at the mandane level. The encounter with a number of obstacles is the establishment of Ariyamagga (the Noble Path). The deep pond surrounded by mountains is probably Samma Samadhi (Right Contemplation), which is the final obstacle along the path.

The fall of the giant demon after the deep pond means that the great obstacles -- the 5 nivarana ( 5 hindrances) are overcome, though one still has other subtle fetters, namely Mana (self-importance), which is more dangerous. Here it is symbolised by the River of Acid. To cross such a river (fetter) one needs the 'python bridge', which probably means the continuity of objectless contemplation. The giant bird symbolizes the pathless way, the spontaneous, transcendental way to Kailasa, the final goal of knowledge. The diamond ring message is the wisdom of seeing into the pure essence of being. Kailasa symbolizes the goal of great knowledge. The approach of Sudhan to Kailasa is the attainment of intuition.

The marriage between Sudhan and Manohara is the re-union of Knowing Mind and bliss. Enthronement and the festival are analogous to Great Enlightenment and joy of living.

It should be noted that Sudhan Jataka is generally known as Pra Suthon-Manohara. Possibly it is the favourite folklore of the people of Southern Thailand. It has been transformed into a dramatic dance called Nora. Although southern scholars have been trying to obliterate the link between Nora and Manohara in order to establish a pure Southern culture, it still seems an attachment to the epilogue without the consideration of its art form and spiritual structure. Nora is the shortened sound of Manohara (Mano means mind and hara means to bring back). She is a kinnari, half-bird / half-human. That is the reason the actor playing her role is dressed in wings at the waist and in the first scene of the performance, another actor wears the mask of the hunter (though today it is very rare to see this). The dramatic dance, Manohara is traditionally and spiritually focused on the gestures of Manohara when she regains 
her wings and tail. ${ }^{3}$ She sings lamentingly for her beloved husband, Sudhan, and moves her wings upward toward Kailasa.

Archaeologically, on the stone wall of the great stupa Borobodur, this story was carved in bas relief. Hence, the story dates back to the Sailendra dynasty of Srivijaya, the south sea kingdom. The structure is nearly the same as Ramayana. The presentation is possibly Vajrayana; Manohara is the equivalent of Sakti or Tara, and Vijjadhara is possibly Vajaradhara.

\section{The Suvarnasangkha Jataka or Sangthong}

Canda Devi, the pregnant queen was sent away from the city by the king, her husband, who was under the evil influence of the second queen and his minister. Canda went to reside in a forest hut with a good-hearted but aged couple. The Bodhisattva Sangthong, from when he was in her womb, intended to take on the form of a golden conch containing the divine treasures within, in order to help care for his mother.

After giving birth to the Bodhisattva in the form of a golden conch, Canda observed that things were always well managed in the hut. One day, pretending to go to the forest, she hid herself to watch her son come out of the conch to help her with the housework so she realized the truth about her beloved son. She destroyed the conch to keep the

\footnotetext{
${ }^{3}$ Avadana: the gem, that enableher to flyin Manohara Cindamani (Cindamani means gem)
}

brilliant Sangthong with her. Sangthong revealed himself to his mother saying, "The golden conch with the treasures within is a divine being. Without it where could I reside harmlessly?" Canda said, "You are the Supreme Being, the most beautiful one. Nobody can win over you; nobody can subdue you. Nothing can harm you" ${ }^{4}$

The king, Sangthong's father, heard the news of his grace and received him and Canda back to the Royal palace again. Soon the jealous queen incited the king against Sangthong and his mother, and deviced various plans to get rid of them but to no avail. Finally, they were abandoned on a raft drawn out to the deep sea. A big storm broke the raft into pieces. Canda reached Madras safely and lived as a house maid in Dhananjaya's family. ${ }^{5}$ Sangthong, however, sank deep down into the sea, to Patala, Realm of the Serpant King (Nagaraya) ${ }^{6}$, where he received bliss and a golden junk. By the power of bliss, Sangthong came to a hermit's ashram on an island. Telling him the way to Varanasi, the hermit instructed him, "If you really want to go, you must follow the tide at the beginning, and arriving at the female-demon's city, you must allow them to capture you, though there shall be no harm to you." ${ }^{7}$

\footnotetext{
${ }^{4}$ Pannasa Jataka, Thai translation, Silpabannagar ed. 1956.

${ }^{5}$ Ibid.

${ }^{6}$ Folklore

${ }^{7}$ Op.cit.
} 
The widowed queen of demons loved Sangthong as her own son. So much so that she tried to prevent his escape. She forbade him to visit the garden, where she left the bones and skulls of humans she had consumed, and also the upper portion of the castle, where the treasures were kept. The five divine treasures were:

1. a well of silver water

2. a well of gold water

3. a pair of golden shoes, allowing the wearer to fly

4. a divine sword, enabling the possessor of which to defeat all enemies

5. a mask of $\operatorname{titan}^{8}$ (Ngoa-pa in Thai and davana in Pali)

When Sangthong realized that the demon queen was a man-eater, he planned his escape. He bathed himself in the silver and gold wells, put on the mask and flew away in the golden shoes with the sword.

The queen of demons followed Sangthong to the end of her realm. Finding herself unable to cross the river which separated the demon's realm from the realm of human beings, in great sorrow she taught the divine mantra to Sangthong, which would give him the power to call and attract the hearts of beasts and fishes. Manoharacindamanimahamantra, a wishing-fulfilling jewel. ${ }^{9}$ was a great mantra, which enabled the possessor to understand the way of all hearts.

${ }^{8}$ Ibid.

${ }^{9}$ Folklore
Sangthong, in the titan mask, arrived at Varanasi ${ }^{10}$ in time for the youngest princess of Varanasi to choose her husband. The six princesses were married to six princes from various countries. Gandha" ${ }^{11}$ vowed to gods that if she was the right bride for Sangthong, she should see Sangthong's inner self. And by the help of the gods she saw the golden self within the titan form, so her garland of love was dropped into Sangthong's hand. Angered, the king sent them to the very border of the country.

The king, planning to kill Sangthong, ordered him to compete with his six sons-in-law in hunting and fishing. ${ }^{12}$ Sangthong called all beasts and fish by the power of his divine mantra. He gave some of those beasts and fish in exchange for the cut-off ears and noses of those six competitors, who found no beast in the forest and no fish in the water.

With the help of God Indra, Sangthong could prove his talent and intelligence in saving Varanasi from its enemies by playing the game of head of the army as his real and golden self riding on a royal horse, he won the game. After marriage with Gandha, he met his beloved mother. He was enthroned as the new king and thereafter the whole kingdom was in peace because of his dharmic administration. ${ }^{13}$

\footnotetext{
${ }^{10}$ Folklore: Samala

${ }^{11}$ Folklore: Rocana

${ }^{12}$ Hunting wild and fishes in Pannasa Jataka

${ }^{13}$ Pannasa Jataka has other episodes after the enthronement.
} 


\section{Summary of Spiritual Glimpse}

Suvarnasangkha or Sangthong possibly symbolizes Bodhi mind (Bodhi citta -the knowing nature which will finally allow one to reach enlightenment). The white conch symbolizes intellect (Sahajatipanna), the worldly wisdom processed by the mind, that assures security in living. To break the conch is to face insecurity, without which one will never realize the essence of Bodhi mind. The nature of mind is the most beautiful and is supreme within itself. When one is aware of such a nature, one has realized the truth of suffering and its cause. Such experiences will awake oneself to the path (magga), beginning the journey into the depth of life, as Sangthong had roamed alone in the deep sea. The golden junk symbolizes pure and shining knowledge, born from experiencing the truth of suffering, though still imperfect. The island ashram of the hermit is the state of being in which one has nearly attained absorption (Jhan). The city of the queen of demons is the realm of trance. The castle is the state of mind in trance. The five treasures are the five factors of Rupa Jhana:

Vitaka is the divine sword. ${ }^{14}$ Vicarana is the pair of gold shoes. ${ }^{15}$

Piti is the well of silver water.

Sukha is the well of gold water.

Ekakhata is the titan mask which transforms the whole body.

\footnotetext{
${ }^{14}$ Diamond sword in folklore

${ }^{15} \mathrm{Gem}$-studded shoes in folklore.
}

In the state of absorption (Jhan), which is an extraordinary experience, the Bodhi mind cannot see things (five skhandas) as they are. One must leave the normal state and gain insight (vipassana) into the Four Noble Truths (mainly suffering and the extinction of suffering); that is why Sangthong left the realm of demons for the human realm (Varanasi).

The six princesses and her six husbands are symbols of the six senses (indriyas) and their objects (aramana). Gandha, the seventh princess, is the Dharmic Eye (Dharmacaksu or Dharmayatana), which is able to see through all forms of suffering (titan form and inner golden form), realizing the true Self which is the golden Sangthong within the titan form. The Dharmic Eye sees the essence of pure being.

The royal horse symbolizes the proper technique for the individual in Dharma practice (kammatthana). The game of kings to win the region means the inner victory of the inner region, which is literally the realization of Dharma through the wisdom of the pure nature of mind with the help of divine beings.

It should be noted that Sangthong is more Buddhistic than SudhanManohara, which has the same structure as Ramayana. Sangthong emphasises the combination of the essence of mind and experiences of suffering, which develops into pure awareness, accompanied by the supramandane power of the practitioner who attains absorption. 
The name Gandha means "fragrant". The non-academic term for Dhammayatana is the seventh ayatan for the theists. The forty war-horses in the royal stable are the forty kammatthanas.

Sangthong is perhaps the favourite tale of the people in the North. Wall paintings from this folklore in the Ubosoth of Wat Bhumin in Nan province are notably the most beautiful example of the northern style.

\section{Rathasena Jataka or Pra Roth- Meree or Nang Sib-Song}

Nanda, the rich father of twelve daugthers, became suddenly penniless, so he had to leave his daughters in the jungle. The twelve sisters, unable to find their way home, approached the garden of Sandhamara Yakkhini, who adopted them as her own sisters. Realizing later that the Yakkhini was a man-eater, the twelve sisters escaped by hiding in the belly of an elephant, a horse and a cow. Hence, they were freed from Sandhamara.

The twelve sisters arrived at Kutanagar, King Rathasiddhi's kingdom, and resided at a big banyan tree near a deep pond. A hunch-backed woman with her gold jar came to fetch pure water for the king. Seeing the golden reflection of the twelve sisters in the water, she misunderstood it to be that of her own self. A feeling of self-importance arose, and the hunch-backed woman destroyed the gold jar and went back to the king without water. The king sent her again with a silver jar, which she also destroyed. Finally, the king sent her with a leather jar. Her crazy manner with the unbreakable jar sent the twelve sisters into fits of laughter. The hunch-backed woman realized her misperception and reported their beauty to the king. The king invited them to his palace and made them his queens. Learning about the whereabout of the twelve sisterts, Sandhamara transformed herself into a most beautiful woman. So the king, intoxicated with her beauty, made her the first queen. Pretending to be ill, Sandhamara made it known to the king that the eyes of those twelve queens was the only medicine for her illness. With the king's permission, Sandhamara took out the eyes of the twelve queens, leaving only the youngest queen one eye. Sandhamara sent all the eyes with the conditioning wind to Kangree (Meree), her daughter who was residing at Gajapuranagar.

King Rathasiddhi could not bear to see the blinded queens. ${ }^{16} \mathrm{He}$ was in great suffering. Under the influence of the first queen, he sent the twelve queens to live in a dark cave. Since there was no food, they were forced to eat their new born children as their daily food. Only the one-eyed sister could save her son Rathasena. The young Bodhisattva had earlier inquired from his mother about

\footnotetext{
${ }^{16}$ According to Pannasa Jataka, this strange sentence suggests the deepmeaning concerning dharma practice that the lack of seeing paticcasamuppada is the cause of suffering.
} 
the true circumstances. With his realization of the situation by the power of Buddha Nature, the cave was alight and opened. Rathasena spoke an epigram to his mother: "We are not two." He then left the cave to seek for food for his mother and aunts.

Gambling with other young boys, Rathasena always won and took only twelve packs of rice and curry for his mother and aunts. Fame in gambling enabled him to come into contact with his father, Rathasiddhi.

Again, Sandhamara pretended to be ill. She planned to kill Rathasena by inciting the king against him and sending him to Kangree, her daugther, for medicine with a secret epistle.

Rathasena chose one eccentric horse from the twenty-two great horses. Testing the power of his horse, he rode through the air for uncountable miles within a few minutes. He named his horse 'Baji'. ${ }^{17}$

On the way to the city of the Demon's daughter, Rathasena visited a hermit who knew the message in the secret letter:

"Whenever Rathasena arrives, be it day or night, kill him."

The hermit changed it to:

"Whenever Rathasena arrives, be it day or night, marry him."

${ }^{17}$ Pannasa Jataka: Baji is the name of a horse but here the author uses this term in the Thai sense, meaning a guide to one who is ordained. (Ba-ji)
Facing innumberable demons at the main entrance of Kangree's city, Rathasena experienced fear and hesitation. Baji (the guide of the practitioner), his brotherly horse, provided him with equine power.

The transformed epistle made Kangree to marry Rathasena with great joy, and wedding festivities followed. She made Rathasena the king of Gajapuranagar. Rathasena indulged himself with Kangree for a couple of months, then the 'guide of practitioner' warned him of his responsibility to his mother and aunts. Rathasena pretended to be ill and asked to take rest in the heart of Kangree's garden. It was a most beautiful garden, with a gate that required one thousand giants to open. This was opened for Rathasena. Riding on horseback he looked around and saw a tree called 'Buddha-punnago'. ${ }^{18} \mathrm{He}$ exclaimed loudly to himself, with the fruit of the tree already in hand, saying ' $\mathrm{O}$ ! mountain punnago tree of Buddha.' ${ }^{19}$

With Rathasena's power, Kangree went into entrancement and told him of the fire place where she kept the eyes of his mother and aunts, also of medicine for curing the eyes and seven other packages of magic powder.

\footnotetext{
${ }^{18}$ Folklore: the tree named 'the neveryawning mango and the never-shouting lemon' in some other parts of Thailand are 'the ever yawning mango and the ever-shouting lemon'.

${ }^{19}$ Pannasa Jataka: pali - Buddhagiripunnago
} 
On horseback Rathasena escaped from his beloved wife. Kangree followed him and tried to get him back with her great powers. Rathasena threw the packages of the magic powder one by one successively to stop her. They became mountain, forest, wind, fire, rain, cloud and lastly ocean, which separated husband and wife completely.

In great sorrow, Kangree entreated Rathasena till her last breath, while the heart of Sandramara also broke.

Rathasena gave the eyes back to his aunts and his mother and applied the medicine to cure them. Their eyes hence became divine.

Rathasiddhi made him the new king and the whole country was again in peace.

\section{Summary of Spiritual Glimpse}

The first thing needed to appreciate this story is the understanding of the Law of Causation (Paticcasamup-pada). The twelve sisters symbolize the twelve links of cause and effect or the Law of Causation. As the heart of Theravada Buddhism, the realization of the Law is defined as seeing Tathagata. Here is the sequence of Paticcasamuppada: Avija - Samkhara - Vinnana - namarupa Salayatana - phassa - vedana - tanha upadana - bhava - jati - jaramarana.

The twelve sisters losing their way in the jungle, then entering the realm of demons and residing in the beautiful garden symbolizes sentient beings that have lost their way in the darkness of ignorance (Avijja), so they remain in the captivity of sensualism till the day they realize that sensual pleasure is actually a 'graveyard' or 'man-eater'. They take refuge in the Triple Gems (Buddha is symbolized by the elephant, Dhamma by the horse, Sangha by the cow) to be free from ignorance.

But one must realize the Four Noble Truths to attain final bliss. Accordingly, one must educate and train oneself in Tri-sikkha (Sila is symbolized by the gold jar, Samadhi by the silver jar, Panna by the leather jar). The hunch-backed woman symbolizes dissatisfaction. Having only Sila and Samadhi is not sufficient. Even panna, or intellectualization of paticcasamuppada, is merely thinking, which is just a shadow or reflection. One needs to have direct experience in dharma practice to attain transcendental wisdom.

Sandhamara is the symbol of desires (tanha) and Kangree, her daughter, is the fetter of passionate delight (nandi). When one loses insight into the Law of Causation, the breathing (wind) is accompanied with nandi, indulging in illusion created by the mind. (The demon took out the eyes of the twelve sisters sending them with the wind to Kangree).

In the truth of suffering there is inherent light of wisdom (the youngest sister was left single-eyed to see things and to take care of her son -- Rathasena).

Rathasena is Bodhi mind, which naturally develops into Enlightened Mind. Rathasena's epigram to his mother: "we are not two" means darkness and light are not a duality; they are not one, yet not two (Advaita or non-duality). 
Though the being is in darkness, suffering in Samsara, the light of pure knowingness makes it possible for life to go on. (Rathasena gambled with the children in order to provide food for his mother and aunts.)

The warhorses are objects of Dharma practice. The horse Baji is Satinpatthana -- the base for development of awareness, which is the only way to attain enlightenment.

The transformation of Sandhamara's epistle is the art of nonresistance. In Dharma practice, if one strongly tries to get rid of defilements and with resistance, one may fall into turmoil. To strongly try to detach oneself is yet another form of attachment. The deceptive ego itself is to be seen. Non-resistance and non-duality is more appropriate.

Marriage between Rathasena and Kangree symbolizes non-duality. It is the art in Dharma practice in order to realize the essence of pure being.

But the practitioner may fall into the trap of pure joy and ignore further practice. One needs the power of mindfulness in order to maintain progressive practice. The Baji horse warning Rathasena is thus symbolic.

The fruit of the Buddhagiripunnago tree, which is in the hand of Rathasena, symbolizes the attainment of the final goal (arahatphala).

The entrancement of Kangree is the fading away of fetters (Nandi). The seven packages of powders are the seven factors of enlightenment, namely:
1. Sati (mindfulness) is the mountain wall protecting the mind from fetters.

2. Dhammavicaya (investigation) is the various trees in the forest.

3. Viriya (effort) is the wind, formless yet blowing continuously.

4. Piti (rapture) as a dire blast.

5. Passaddhi (tranquility) is rainfall.

6. Samadhi (contemplation) is a cloud floating in the sky.

7. Upekkha (equanamity) is the ocean.

The Bodhi mind (knowing nature) is completely free from all forms of attachment. There are no more fetters. That is the fall of Kangree. Her mother, which symbolizes desire (tanha), simultaneously came to an end.

Complete enlightenment is brought to life by insight into the Law of Causation. The divine eye is the spiritual symbol of transcendental wisdom. The enthronement and great festival symbolize the great virtue and the great joy realized after enlightenment.

It should be noted that Rathasena Jataka or Pra Roth-Meree is the only folktale containing various themes of Dharma: Paticcasamuppada (Dependent origination), Sattabhoji-hanga (seven factors of enlightenment), Tisarana(the three Refuges), Trisikkha (three trainings), etc. 


\section{Note on Differences and Unity of the Three Epics}

The three stories were chosen as examples for study because their spiritual structure, personification and symbolical presentations and the relation of this elements are different. SudhanManohara has the same structure and symbolical presentation as Ramayana. For example, Kailasa is the equivalent of Lanka, Rathasena is like Rama, Manohara is like Sita. The journey into the jungle, the killing of the demons, the monkeys, the big bird (as Jataya and Samvadi). have the same symbolical meaning. It is possibly influenced by Ramayana. The relation between the structure and symbolism is characterized by Mahayana Buddhism, which is possibly why this story was carved on the stone walls of the great stupa of Borobodur.

Sangthong is more Theravadian than Sudhan-Manohara. The symbolism is more Buddhistic in meaning. Besides the cities, the setting of SudhanManohara is the jungle and the mountains while Sangthong took place at sea, on an island and in the forest.

Roth-Meree is possibly the most Theravadian in nature. As Manohara of Sudhan Jataka and Gandha (Rocana) of Sangthong represent Sakti (potentiality) or Tara, Vasundra, the consort of Avalokitesvara Bodhisattva of Mahayana Buddhism, Meree of Rathasena Jataka, is the fetter - the obstacle of the mind in Theravadian Buddhism.

\section{Epilogue}

To have a glimpse into the spiritual depth of Thai epics or folklore, it is necessary to understand Buddhism, because it influences both the social consciousness of the Thai people and their inner being, from the past to the present time. Epics or folklore both in written form and in verbal form reflect symbolically the way of Thai living.Thai folklore, like folklore of other countries, has spiritual essence as the goal but also provides entertainment. This spiritual essence is presented by the use of personification and symbolism, through the behaviour of heroes and heroins, animals, demons, etc. If the key to this spiritual depth is lost, it would be a considerable loss.(to the total meaning of those epics and folklore.)

This article does not aim to establish an encyclopedia of symbols but to give a glimpse of the spiritual aspects of Thai folklore. We may understand its essence by interpretation; otherwise we may be confused by the details which have been socialized as time goes by. Flexibility is often found in Thai character, both in artistic expression and in behaviour. The glimpse of spiritual meaning in folklore is merely attainable probability by other means than meditation. Also other kinds of art, particularly poetry, are concerned with thinkable or imaginable forms, hence it cannot represent what is beyond thoughts and imagination. A deep understanding and appreciation of spiritual folklore may come to light only by meditation, to realize the formless, the abstract forms, the extinction of forms, and finally detachment. Such realization is the basis of understanding and appreciation Thai epics and folklore, since 
all inner happenings are symbolized by various elements in the story like incidents, setting or characters such as Kailasa Mountain, gods, demons, mask of a titan.

It is questionable whether in our modern times there is any epic or folklore of the same depth as those in the glorious past. Our responsibility is not merely to evaluate folklore at psychological and philosophical levelaall inner happenings are symbolized by elements in story like incidents, setting or characters such as Kailasa Mountain, gods, demons, titans nor Kailasa.

It is questionable whether in our modern time there is any epic or folklore of the same depth as those in the glorious past. Our responsibility is not merely to evaluate at a psychological and philosophical levels but to put Dharma into practice, in order to know oneself, and understand the spiritual meaning of the folklore which illuminates a new means of living by wisdom, in peace and love. 